\title{
Determining the Applicability of DNA Evidence in Rape Trials in India
}

\author{
Dipa Dube (Corresponding author) \\ Indian Institute of Technology Kharagpur, \\ Kharagpur 721302, West Bengal, India \\ E-mail: dipa.dube@gmail.com
}

Received: February 18, 2014

Accepted: March 12, 2014 Published: March 21, 2014

doi:10.5296/ijssr.v2i1.4966

URL: http://dx.doi.org/10.5296/ijssr.v2i1.4966

\begin{abstract}
The paper seeks to delve into the efficacy of DNA technology in securing justice in criminal trials pertaining to rape. An analysis of rape cases over the last decade has been done in order to assess the use of DNA in rape trials in India and the reliability placed on such evidence by the courts.
\end{abstract}

Keywords: DNA, Rape, Criminal Trial, Evidence

\section{Introduction}

Rape is a horrendous crime perpetrated against humanity. It is the most brutal and demeaning act of coercive sexual intercourse by a man on a woman. It destroys the entire physical and psychological composure of a woman and reduces her to a living corpse. As opined by the Supreme Court of India, rape is an experience, which shakes the foundations of the lives of its victims.

Securing conviction in Rape Trials is an arduous task. As is oft quoted, it is hard to get a case of rape reported, and it is even harder to get it proved. The reasons for the same may be numerous. While on the one hand, delayed reporting of cases is detrimental, on the other, sloppy investigation, inconsistent victim statements, hostile witnesses etc. are material in failure of prosecution in establishing the guilt. An important factor, in rape trials, is scientific evidence. It is this element which connects the offence with the accused. The presence of semen in the private parts of the woman, and /or the clothes of the victim may go a long way in establishing the guilt of the accused. In fact, DNA has proved to be one of the most precise methods of crime detection and is increasingly being used, for the purposes of accuracy, in 
trials in different parts of the globe. This brings us to the next aspect of human rights. As reported in the United States on Exonerations for Serious Crimes, 2003, "In 88\% of the rape cases, the exonerations were based on DNA evidence; $20 \%$ of the murder exonerations involved DNA, almost all of them for homicides that also included a rape. The large number of rape exonerations is due to the unique power of DNA to detect false convictions for rape."

To what extent is the scientific technology made use of in India is the subject matter of inquiry in the present paper and through the means of case analysis, the author has tried to analyze its applicability in present day rape trials.

\section{DNA Technology}

The impact forensic DNA has had on our modern society can hardly be overstated. It has affected our perceptions of past societies and continues to be a disruptive technology changing the way everything works. Advances in DNA analysis have not only allowed for personal identification from biologic material but have greatly increased the kinds of biological material that can be analyzed. Discovered in 1984 by Sir Alec Jeffreys, DNA typing has heralded a new era in forensic science and genetic research ${ }^{1}$.

Deoxyribonucleic acid (DNA) is a polymer, a molecule made of smaller repeating units called monomers. DNA is present in nearly all living cells except in the red blood cells and nerve cells. Forensic science uses 2 types of DNA: nuclear and mitochondrial. Nuclear DNA resides in the nucleus of the cell and contains the information for growth and maintenance of that cells functions. Mitochondrial DNA resides in a subunit of active cells, called the mitochondrian, that play a role in energy production for the cells ${ }^{2}$. There are several techniques of DNA identification:

\section{a. Restriction fragment length polymorphism(RFLP) ${ }^{3}$}

RFLP is a technique for analyzing the variable lengths of DNA fragments that result from digesting a DNA sample with the special kind of enzyme. These enzymes, restriction endonuclease, cut DNA at the specific sequence pattern known as the restriction endonuclease recognition site. The presence or absence of certain recognition sites in a DNA sample generates variable lengths of DNA fragments, which are separated using gel electrophoresis. They are then hybridized with DNA probes that bind to a complementary DNA sequence in the sample.

RFLP was one of the first applications of DNA analysis to forensic investigation. With the development of newer, more efficient DNA analysis techniques, RFLP is not used as much as once was because it requires relatively large amounts of DNA. In addition, samples as degraded by environmental factors, such as dirt or mold, do not work well with RFLP.

\footnotetext{
${ }^{1}$ Max M. Houck, Forensic Science Modern Methods of solving Crimes, Macmillan Rep. India 2008, p 103-104.

${ }^{2}$ Id.

3 See, ED Johnson and Thomas M. Kolowski, Chemiluminescent Detection of RFLP Patterns in Forensic DNA Analysis, Journal of Forensic Sciences, Vol. 41, July 1996, pp.569-578; L. Singh, DNA Profiling and its Applications, Current Science Journal, Vol. 60-, 1991 pp. 9-10.
} 
b. PCR analysis

Polymerase Chain Reaction (PCR) is used to make millions of exact copies of DNA from a biological sample. DNA amplification with PCR allows DNA analysis on biological samples as small as of few skin cells. With RFLP, DNA samples would have to be the size of a quarter. The ability of PCR to amplify such tiny quantities of DNA enables even highly degraded samples to be analyzed. Great care however, must be taken to prevent contamination with the other biological materials during the identification, collection and preservation of the sample ${ }^{4}$.

c. STR analysis

Short tandem repeat (STR) technology is used to evaluate specific regions (loci) with the nuclear DNA. Variability in STR regions can be used to distinguish one DNA profile from another. The Federal Bureau of investigation uses the standard set of 13 specific STR regions for CODIS. CODIS is a software program that operates local, state and national database of DNA profiles from convicted offenders, unsolved crime scene evidence and missing persons. The odds that 2 individuals will have the same 13 loci DNA profile is about one in 1 billion.

\section{d. Mitochondrial DNA analysis}

Mitochondrial DNA analysis (mtDNA) can be used to examine the DNA from samples that cannot be analyzed by RFLP or STR. Nuclear DNA must be extracted from samples for use in RFLP, PCR and STR; however, mtDNA analysis uses DNA extracted from another cellular organelle called a mitochondrion. While older biological samples that lack nucleated cellular material, such as hair, bones and teeth, cannot be analyzed with STR and RFLP, they can be analyzed with mtDNA. In the investigation of cases that have gone unsolved for many years, mtDNA have proved to be extremely valuable.

\section{Use of DNA in Administration of Justice}

DNA is found in every living cell of our bodies and can, therefore, be extracted from our whole variety of different materials like blood, semen, hair, saliva, urine, bone marrow, body tissues etc. The DNA offers the possibility of determining whether the blood, semen or other deposits located at the scene of a crime come from a person suspected of having committed the crime. Forensic Investigators seek biological evidence samples 1 . At the scene of a crime 2. At a location which is related to the crime, or 3. From the clothes of the victim or suspect which are recovered at a later time. Biological evidence is generally transferred either by direct deposit, or by secondary or in direct transfer. In direct deposit, fluid biological specimens, such as blood, semen or saliva, as well as non-fluid specimens such as hair, tissue, bone are transferred by direct contact and deposited. Once fluid specimens are deposited, they become stains and adhere to the surface or substratum. In secondary transfer, blood, semen, hair, saliva or urine is transferred to a victim, suspect, witness object or location through an intermediate medium ${ }^{5}$. It is particularly useful in investigation of Murder or sexual offences, paternity disputes, child

\footnotetext{
4 See, George F. Sensabaugh, The Polymerase Chain Reaction, Journal of Forensic Science, 31 J. Forensic Sci. Soc'y 201 (1991);

${ }^{5}$ Lee, Guidelines for the Collection and Preservation of DNA Evidence, 2-3 (U.S. Dept. of Justice, FBI, 1990).
} 
swapping cases and accident cases. Forensic investigators who respond to the scene of a crime seek DNA evidence samples inadvertently left behind by the suspect. For example, during the course of a rape or sexual assault, the suspect's semen may be found in vagina or mouth or on skin and other topical surfaces of the body of the victim, or as wet or dry stains on her undergarments ${ }^{6}$. A suspect's skin may become lodged under the fingernails of the victim where the latter scratches the suspect in an attempt to escape. A suspect or victim who is injured or wounded in course of the assault may leave behind blood on the body or cllothes. At an indoor crime scene, evidence samples may be recovered on virtually any surface, such as bed sheets and bedspreads ${ }^{7}$.

One of the earliest uses of DNA in forensic setting was in 1983 with regard to establishing identity in an immigration case. ${ }^{8}$ However, one of the first criminal convictions based on DNA profiling evidence occurred in the rape case of Robert Melias in 1985. DNA test successfully helped to establish guilt of Melias after he was confronted with evidence of a DNA match of his DNA pattern and that of a semen stain left on the clothing of a 43 year old handicapped woman he raped. He was convicted of rape and sentenced to 8 years in jail ${ }^{9}$.

Subsequently, DNA has heralded a new age of scientific investigation, involving speedier, specific, accurate and conclusive forensic evidence in place of the archaic human evidence. As noted by Dr. S.N. Tewari, it is true that science does occupy an important and unique role in the criminal justice system - role that relates the scientist's ability to supply accurate and objective information that reflects the events that have occurred at the time of crime. It has made a significant impact on the societies determined effort to meet the challenge of alarming increase in sophisticated crimes and violence. In fact, today it has become imperative that Law and order agencies should be basically assisted by modern scientific aids, as offered by forensic science in protecting the innocent and punishing the culprit. The conventional reliance on the subjective knowledge of eye witness and the verbal testimonies as a proof of guilt or innocence are neither practicable, nor reliable today. Forensic science has offered a new technology to police work and revolutionaries an important aspect of human activity. ${ }^{10}$

\section{Significance of DNA Evidence in Rape}

"The most dreaded, yet to be most frequent; the most tabooed, yet the most discussed; the most traumatic, yet be most discarded; possibly, that is how one would describe the term rape". Rape is the most gruesome and barbaric act perpetrated upon woman ${ }^{11}$. It is a gross violation of her bodily integrity and honor. Rape may be viewed as an act of violence of the private person of a woman, and outrage by all means. Rape is not merely a physical assault but is destructive of the

\footnotetext{
${ }^{6}$ Andrews v. State (1988 Fla App D5) 533So 2d 841, 13FLW 2364; Nelson v. State (1993, Del Sup) 628A2d 69; People v. Mehlberg (1993, $5^{\text {th }}$ Dist) 249 III App 3d 499, 188 III Dec 598, 618 NE2d 1168.

7 Spencer v. Commonwealth (1990) 240Va 78, 393 SE2d 609; People v. Soto (1994, $4^{\text {th }}$ Dist) 30 Cal App $4^{\text {th }}$ Cal Rptr 2d 846, 94 CDOS 8893, 94 Daily Journal DAR 16477.

${ }^{8}$ Alec J. Jeffrey (et.al), Positive identification of an immigration test-case using human DNA fingerprints 317 Nature 818 (1985).

9 Available at http://www.historybytheyard.co.uk/dna.htm\#Robert Melias (last visited on $3^{\text {rd }}$ Nov 2013).

10 S.N. Tiwary, Role of Forensic Science in Detection of Crime, Criminal Law Journal, 1996, p. 138.

11 In India, till date, rape is perceived as a women centric offence. Section 375 Indian Penal Code, 1860 starts with the words "A man is said to commit rape if he...". Thus, women can only be the victims of the offence while men may be the perpetrators.
} 


\section{Macrothink}

whole personality of the victim. It shatters the entire social fabric, destroys the poise of the milieu and ruins the harmony of the atmosphere ${ }^{12}$. The Apex court of India has aptly described it as ${ }^{13}$ the most morally and physically reprehensible crime in a society, as it is an assault on the body, mind and privacy of the victim. While a murderer destroys the physical frame of the victim, a rapist degrades and defiles the soul of a helpless female. Rape reduces a woman to an animal, as it shakes the very core of her life. By no means can a rape victim be called an accomplice. Rape leaves a permanent scar on the life of the victim, and therefore a rape victim is placed on a higher pedestal than an injured witness. Rape is a crime against the entire society and violates the human rights of the victim. Being the most hated crime, rape tantamounts to a serious blow to the supreme honour of a woman, and offends both, her esteem and dignity. It causes psychological and physical harm to the victim, leaving upon her indelible marks.

The offense of rape can safely be termed as the 'burning problem' of India. In spite of measures to curb its occurrence at the legislative and executive level, the crime has continued to steadily increase over the years. From 16373 incidents of rape reported in the year 2002, the number has increased to 24723 in 2012, a period of 10 years. The offence of rape has thus recorded a $51 \%$ increase in the last decade. It must be remembered that these figures are indicative of the reported cases and not the actual figures, since thousands of such cases go unreported due to fear of social stigma, ostracisation, reprisal etc.

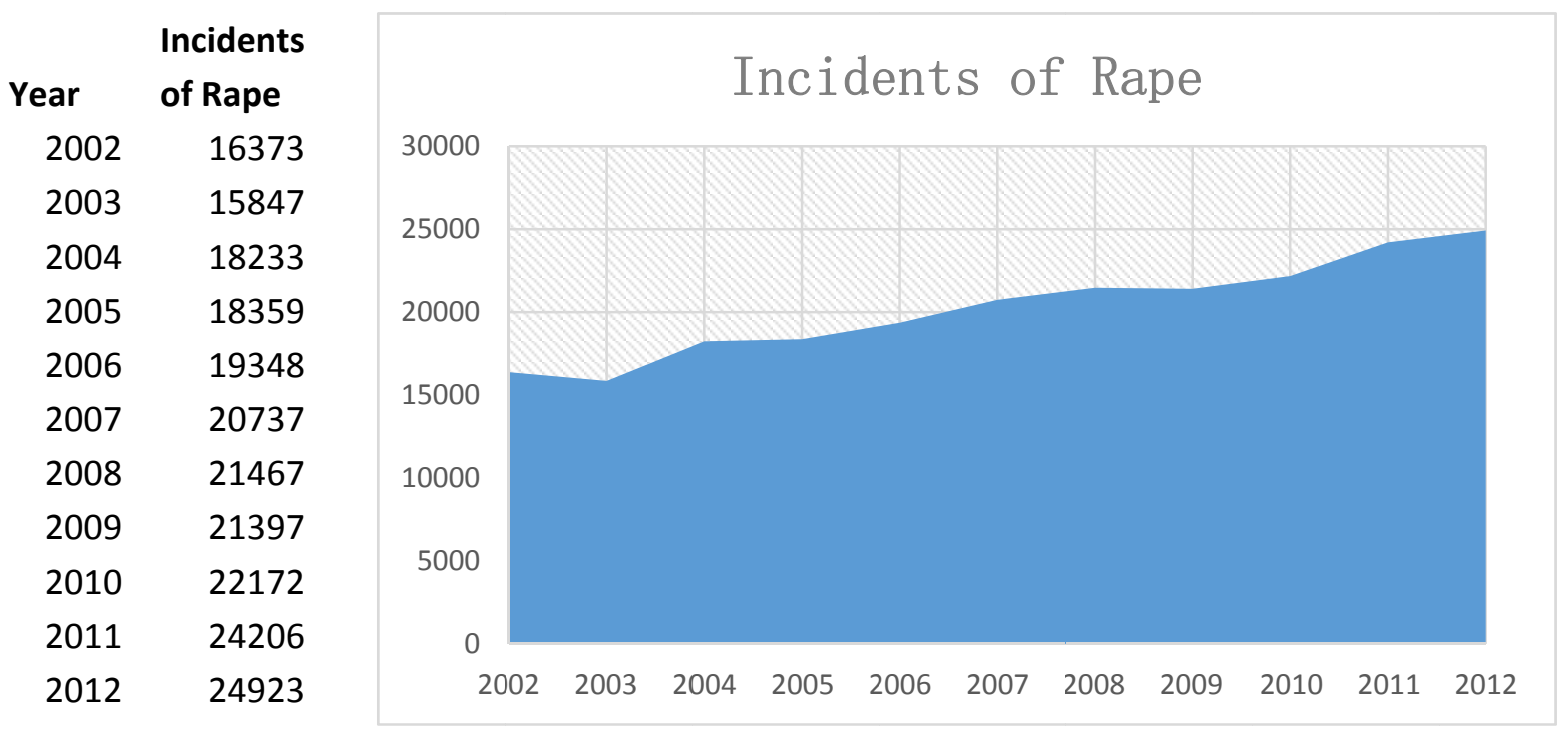

Source: Crime in India. NCRB, Government of India.

Figure 4.1 Incidents of Rape in India

\footnotetext{
12 Dipa Dube, Rape Laws in India, Lexis Nexis Butterworths, New Delhi, 2008; See, State of Punjab v. Ramdev Singh Manu/SC/1063/2003

${ }^{13}$ Deepak Gulati v. State of Haryana 2013(2)ACR2308
} 
The unabated occurrences have been coupled with sloppy investigations, delayed trials and finally, acquittal of the accused. According to figures, by the end of 2012, 14.9\% of rape cases had been disposed of by Courts, while an overwhelming $85.1 \%$ cases remained pending. The conviction rate, i.e., the ratio of cases convicted to the total cases tried, in the year 2012 was merely $38.5 \%$ which was less as compared to $41.1 \%$ in the year 2011 .

"In our criminal justice system, rape crimes are often difficult to prosecute..." the gravity of the situation demands a change in the way investigations are carried on and trials are conducted, reality indicates somewhat differently. In rape trials, the woman's evidence coupled with her conduct and medical evidence goes a long way to prove an accusation. In most cases, however, the woman is disbelieved and her statement is discarded as being that of an accomplice "We find that in rape trials the woman's evidence is invariably dismissed and she herself found to be a consenting party, if she waves from her initial statement even by hair's breadth... When a woman undergoes so great a trauma as rape she is expected to remember every detail, every moment with photographic precision and clarity... She is also expected to find unusual mental and physical reserves to fight the rapist and have sufficient initiative to otherwise save herself. If a woman suffers from any other nonsexual trauma, the court would expect her to be dazed, even catatonic. But not when she is raped. Not even when it is a case of multiple rape." 15

Next, is the issue of corroboration of the testimony of the victim. While no law states that a conviction cannot be based on the uncorroborated testimony of the victim, yet as a matter of prudence and caution, the court insists on corroboration of the statement of the victim, so as to satisfy its conscience that she is telling the truth and that the person accused of rape has not been falsely implicated ${ }^{16}$. In Narendra Kumar v. State of Delhi ${ }^{17}$ the Supreme Court stated the position thus: Conviction can be based on sole testimony of the prosecutrix provided it lends assurance of her testimony. However, in case the court has reason not to accept the version of prosecutrix on its face value, it may look for corroboration. In case the evidence is read in its totality and the story projected by the prosecutrix is found to be improbable, the prosecutrix case becomes liable to be rejected. Corroboration may come from other witnesses or else, medical evidence in the case. The offence of rape rarely finds an eye witness, it is an offence committed in private space and out of the sight of others; thus, witnesses are rare to come by. The conduct of the victim in confiding the same to others immediately after the occurrence has been relied upon by the courts, but, in most cases, such narrations are to the family members or friends, who may be taken as 'interested or partisan' witnesses.

\footnotetext{
14 Stephanie A. Parks, Compelled DNA Testing in Rape Cases: Illustrating the Necessity of an Exception to the

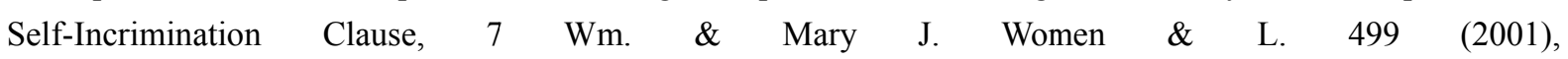
http://scholarship.law.wm.edu/wmjowl/vol7/iss2/7

15 Vasudha Dhagamwar, Law Power and Justice: The Protection of Personal rights in the Indian Penal Code, Sage Publications, India, Second Edn., 1992, p.251.

${ }_{16}$ See, Gurcharan Singh v. State of Haryana Manu/SC/0131/1972

17 AIR 2012 SC 2281
} 


\section{MInstitute Macrothink $_{\text {Int }}$}

The issue of medical evidence also poses a problem as the lack of necessary knowledge on the part of the victim results in delayed reporting of the matter, delayed medical examination and thereby, lost evidences. As seen in Sheikh Zakir v. State of Bihar" "the complainant and her husband being persons belonging to a backward community like the santhal tribe living in a remote area would not be expected to know that they should rush to a doctor. In fact the complainant had deposed that infact she had taken a bath and washed her clothes after the incident. The absence of injuries on the person of the complainant may not by itself discredit the statement of the complainant. Merely because the complainant was a helpless victim who was by force prevented from offering serious physical resistance she cannot be disbelieved. In this situation the nonproduction of a medical report would not be of much consequence if the other evidence on the record is believable." The past sexual history of the victim also comes in the way of negating a rape charge. In the land mark case of Tukaram v. State of Maharashtra ${ }^{19}$ the court branded the victim as a 'shocking liar' whose testimony 'is riddled with falsehood and improbabilities'. The previous conduct of the victim in eloping with her lover and being habituated to the act of sexual intercourse influenced the mind of the judges and they disbelieved the story of the victim girl. In State of Punjab v. Gurmit Singh ${ }^{20}$ the ignorance of the victim girl about the make of the car in which she had been abducted, the delay in the filing of FIR, the absence of any independent evidence to corroborate her testimony and the medical report that she might have had physical contacts earlier, assured the high court that the prosecutrix was a girl of immoral character who had made a false accusation of rape. Fortunately, however, the findings were reversed by the Supreme Court and it went on to hold that, even if a woman had been promiscuous in her sexual behavior, she has the right to refuse herself to anyone and no stigma can be cast on her.

Inspite of the words of Court, where a sympathetic and considerate view towards the victim has resonated, the reality remains that rape continues to be a traumatic experience for the victim. The pain is further heightened where the victim chooses to report the matter to the enforcement agencies and proceed for prosecution. Identifying the rapist, establishing the factum of the offence and finally, proving the point of 'no-consent' on the part of the victim is a rigorous exercise. The high standards of evidence required to establish each point before the court beyond all reasonable doubt further aggravates the pain and humiliation of victim. "The process of prosecuting a rapist can have a traumatic and devastating effect on a rape victim because, among other reasons, conviction is often difficult to achieve. There are many psychological reasons victims choose not to prosecute. Often, the process is simply too emotionally traumatic to endure. If a victim decides to prosecute and the jury does not find in her favor, she usually feels betrayed by a system that she believes should protect her. Such a result often destroys any psychological progress the victim may have experienced after the rape. Apprehending a rapist is difficult; proper and accurate identification of him for prosecution is even harder. Even when the police submit cases to a prosecuting attorney, it is

\footnotetext{
18 AIR 1960 SC 911

19 AIR 1979 SC 185

20 AIR 1996 SC 1393
} 
doubtful there will be many convictions... The problem, therefore, does not seem to be with the criminal justice system's ability to punish rapists, but with its ability to convict them."21

Herein comes the efficacy of DNA as a crucial piece of evidence. DNA analysis has become a mainstay of the criminal justice system - the gold standard for identification. DNA is unique among identifying evidence in both its durability and its degree of reliability. DNA's degree of certainty is so high that under some circumstances it is likely to outweigh all other evidence in the original record" 22 .DNA evidence and typing procedures are uniquely useful in sexual assault cases because conventional analysis cannot differentiate between blood groups found in secretion stains containing both seminal and vaginal fluids. Therefore, if the rapist and victim had the same blood type, the scientist would not be able to determine from whom the sample was derived. DNA analysis eliminates this problem, as current technology can distinguish between the DNA from the victim's vaginal tract and the rapist's semen. Forensic scientists need only a small sample of tissue, such as a hair or a spot of dried blood or semen for DNA analysis. To get a decisive match or exclusion, an expert makes a comparison of the DNA profile of the evidence sample with the profile of a blood sample taken from the suspect or victim. In theory, DNA-based profiles are better absolute identifiers than fingerprints because they are subject to less deterioration or tampering and more likely to be retrieved as evidence. Seminal fluid itself does not contain DNA, but spermatozoa does. Because semen normally contains a large number of spermatozoa, there is a correspondingly large quantity of DNA available for analysis when a semen sample is available. In seminal stains that lack spermatozoa, such as in the case of a sterile rapist, 'it may still be possible to obtain a DNA type from epithelial tissue or white blood cells present in the stain.' Like seminal fluid, saliva does not contain DNA; again, there would likely be epithelial tissue or white blood cells present which may be typed for DNA. DNA can also be extracted from bloodstains via the white blood cells. DNA evidence is especially helpful in rape cases because it is often impossible to accurately identify a perpetrator. DNA testing arguably provides proof of the perpetrator's identity. In fact, due to its accuracy, DNA has been touted as the most important advancement in defendant identification to date' and has helped exonerate or incriminate rape suspects." 23 As opined by Kirby "The collateral benefits of DNA analysis for the criminal justice system are also impressive. ... It has been reported that most rape defendants confronted with DNA test results implicating them have pled guilty.... As a corollary to the increase in guilty pleas because of overwhelming DNA evidence, victims may be more willing to report rapes to police. One deterrent to reporting is the additional trauma incurred by victims while testifying at a trial. The increased likelihood of guilty pleas generated by the DNA analysis may diminish that deterrent.. Moreover, reports

\footnotetext{
21 Supra n. 13 at p.503-4; "The victim who goes to court often has high expectations that this will be the culmination of all her difficulties with the rape and expects to be able afterwards to "start a new life. Unfortunatelly, for most women this is not true. The low conviction rate on rape cases is notorious. ... The gap between the victim's expectations and the reality of the situation makes later adjustment even more difficult.” Sedelle Katz \& Mary Ann Mazur M.D., Understanding the Rape Victim: A Synthesis of Research Findings, Wiley-Interscience, New York City, 1979, p. 199.

${ }^{22}$ David Lazer and Michelle N. Meyer, DNA and Criminal Justice System: Consensus and Debate, pp.880-1 Available at http://www.hks.harvard.edu/davidlazer/files/papers/Lazer_Meyer-DNA-book-Conclusion.pdf

${ }^{23}$ Supra n. 13, pp.508-9.
} 
have indicated that rape victims are more likely to file a complaint if there is a high probability of conviction, and they are less likely to make a report when the probability is low. DNA testing should increase dramatically the convictions in non-acquaintance rape cases."24

\section{Indian Legal Scenario}

Whether the legal ground in India is geared for the acceptability and admissibility of DNA evidence is ambivalent. With most legislations being of colonial origin, there is little scope for introduction of DNA as a significant evidence in criminal trials. Nevertheless, the accuracy and reliability of DNA analysis over the years across jurisdictions has somewhere compelled the judicial system to take note and gradually make way for its increased usage.

\subsection{Rights vs. Legal Obligation}

One of the fundamental issues which has posed a barrier to its smooth inclusion is the Right against Self Incrimination, a right guaranteed under Art. 20(3) of the Indian Constitution ${ }^{25}$ which protects an accused person in criminal cases from providing evidences against himself. The fundamental right guaranteed under Article 20(3) is a protective umbrella against testimonial compulsion in respect of persons accused of offence to be witness against themselves. The protection is available not only in respect of evidence given in a trial before Court but also at previous stage if the person is accused when he made the statement. The protection against self-incrimination envisaged in Article 20(3) is available only when compulsion is used and not against voluntary statement, disclosure or production of document or other material ${ }^{26}$.This is particularly significant in the backdrop of Section 53 of the Code of Criminal Procedure, $1973^{27}$ which enables the Investigation Officers to conduct

\footnotetext{
${ }^{24}$ Lorne T. Kirby, DNA Fingerprinting: An Introduction, Oxford Univ. Press, 1990, p. 190-1.

25 Art 20(3) of the Constitution of India reads as: Protection in respect of conviction for offences.- No person accused of any offence shall be compelled to be a witness against himself.

${ }^{26}$ Justice U.C. Srivastava, Immunity from Self Incrimination under Article 20(3) of the Constitution of India, 2(4 \& 5), JTRI Journal 1996, p.2.

27 Section 53 Code of Criminal Procedure 1973 reads as : (1) When a person is arrested on a charge of committing an offence of such a nature and alleged to have been committed under such circumstances that there are reasonable grounds for believing that an examination of his person will afford evidence as to the commission of an offence, it shall be lawful for a registered medical practitioner, acting, at the request of a police officer not below the rank of sub-inspector, and for- any person acting in good faith in his aid and -under his direction, to make such all examination of the person arrested as is reasonably necessary in order to ascertain the facts. which may afford such evidence, and to use such force as is reasonably necessary for that purpose.

(2) Whenever the person of a female is to be examined under this section, the examination shall be made only by, or under the supervision of, a female registered medical practitioner.
}

Explanation. - In this section and in sections 53A and 54,-

(a) "examination" shall include the examination of blood, blood stains, semen, swabs in case of sexual offences, sputum and sweat, hair samples and finger nail clippings by the use of modern and scientific techniques including DNA profiling and such other tests which the registered medical practitioner thinks necessary in a particular case; (b) "registered medical practitioner" means a medical practitioner who possess any medical qualification as defined in clause (h) of section 2 of the Indian Medical Council Act, 1956 and whose name has been entered in a State Medical Register. 
investigation through scientific approach by conducting medical examination of the accused through a registered medical practitioner in order to afford evidence as to the commission of the offence. The Law Commission of India ${ }^{28}$, has stated the position thus: "The commission has considered at length the question as to how far the physical examination of the arrested person is legally and constitutionally permissible and what provision, if any, should be made in the code for the purpose. It came to the conclusion that a provision on the subject was needed and recommended a new section authorizing, in certain circumstances and subject to certain safeguards, the examination of person of the accused by a qualified medical practitioner. We agree that such provision is necessary for effective investigation and will not offend against Article-20(3) of the Constitution." There is nothing brutal or offensive or shocking in taking the blood sample under the protective eye of law. This is one of the well-recognized methods adopted in crime detection all over the world. Section 53 of the code imposes an obligation upon the arrested person to subject himself for medical examination at the instance of police officer to help the investigation. The constitutional mandate does not say that no person shall be deprived of his right or personal liberty under any circumstances. On the contrary, if such deprivation of right or personal liberty is in accordance with the procedure established by law, the same does not violate Article 21 of the Constitution of India ${ }^{29}$.

In this connection, a reference may be made to the judgment rendered by High Court of Andhra Pradesh in the case of Ananth Kumar Naik v. State of Andhra Pradesh ${ }^{30}$. The Court, while considering the scope of Section 53 of the Code observed that "Examination of person by a medical practitioner must logically take in examination by testing his blood, semen, urine etc." The Court further observed that Section 53 of the code provides for use of such force as is reasonably necessary for making such examination. Therefore, whatever discomfort might be caused when samples of blood and semen are taken from an arrested person, would be justified under the provisions of Section 53 and 54 of the Code. The Division Bench of Allahabad High Court, in the case of Jamshed v. State of UP ${ }^{31}$ has also taken the view that though there is no specific provision under the Indian law permitting taking the blood sample, yet, in criminal case, "examination of a person" includes an examination of any organ inside the body, and taking of blood sample also. It is observed that in modern society, taking of blood could not be said to be something offensive or against the sense of decency and that there is nothing repulsive or shocking to the conscience in taking

$2841^{\text {st }}$ Report on The Code of Criminal Procedure, Law Commission of India, Government of India, Sept. 1969, para 5.1 .

29 H.M. Prakash v. State of Karnataka ILR 2004 Karnataka 2637; See, Miss. Swati Lodha v. State of Rajasthan MANU/RH/0088/1990; Anil Anantrao Lokhande v. The State Of Maharashtra MANU/MH/0005/1980; Amarjit Kaur v. Harbhajan Singh and Ors., 2002 (8) Scale-260; Goutam Kundu v. State of West Bengal and Anr., AIR 1993 SC 2295; State of Bombay v. Kathi Kalu Oghad, AIR 1961 SC 1808; M.P. Sharma and Ors. v. Satish Chandra AIR 1954 SC 300;

${ }^{30}$ MANU/AP/0220/1977

${ }^{31}$ MANU/UP/0239/1976 
the blood sample. As such, even causing some pain in the process may be permissible under Section 53 of the Code. The Allahabad High Court, in the case of Neeraj Sharma v. State of U.P. ${ }^{32}$ while discussing the power of the Magistrate to direct medical examination under Section 53 of the Code held thus: "It will not be proper to give a restricted meaning to the word 'examination' used in Section 53 of the Code. The examination of the accused should mean a complete examination which a medical practitioner may like to have by all modern and scientific tools available in order to give his opinion and it should not be confined to a superficial examination by merely having a look at the body of the accused. In fact a doctor who is trained and is used to employing modern day technique for diagnosis may refuse to give his opinion unless he performs the necessary scientific tests in this regard. The legislature was also conscious of this and has, therefore, made a specific provision permitting use of force while enacting Section 53 in the Code of 1973." "Therefore, a Magistrate has full power to direct that a medical examination of the accused be performed or samples of his hairs, nails etc., be taken where the offence alleged to have been committed is of such a nature and is alleged to have been committed under such circumstances that there are reasonable grounds for believing that such an examination will afford evidence as to the commission of offence.",33

In the celebrated case of State of Bombay v. Kathi Kalu Oghad ${ }^{34}$, the Hon'ble Supreme Court considered the similar question in relation to Article 20(3) of Constitution of India and also re-examined some of the propositions laid down in the case of M.P. Sharma And Ors. v. Satish Chandra ${ }^{35}$. It is held therein that 'to be a witness' in relation to oral evidence means "imparting knowledge in respect of relevant facts by a person who has personal knowledge of a fact to be communicated to a Court." It was further observed that Section 139 of the Evidence Act recognizes the distinction between producing a document and being a witness, for it provided: "a person summoned to produce a document does not become a witness by mere fact that he produced it and cannot be cross examined unless and until he was called as a witness". In the said judgment, the Hon'ble Supreme Court, after considering various aspects, came to the following conclusions:

(3) 'To be a witness' is not equivalent to 'furnishing evidence' in its widest significance; that is to say, as including not merely making of oral or written statements but also production of documents or giving materials which may be relevant at a trial to determine the guilt or innocence of the accused.

(4) Giving thumb impressions or impressions of foot or palm or fingers or specimen writings or showings parts of the body by way of identification are not included in the expression 'to be a witness'.

(5) 'To be a witness' means imparting knowledge in respect of relevant facts by an oral statement or a statement in writing, made or given in Court or otherwise,

\footnotetext{
${ }^{32}$ MANU/UP/0248/1992

33 See, Ritesh Sinha v. State of Uttar Pradesh AIR 2013 SC 1132.

34 1961CriLJ856

35 AIR 1954 SC 300
} 
(6) 'To be a witness' in its ordinary grammatical sense means giving oral testimony in Court. Case law has gone beyond this strict literal interpretation of the expression, which may now bear a wider meaning, namely, bearing testimony in Court or out of Court by a person accused of an offence, orally or in writing."

More recently, in the case of Selvi ${ }^{36}$, the Supreme Court referring to Kathi Kalu opined that Article 20(3) aims to prevent the forcible conveyance of personal knowledge that is relevant to the facts in issue. The results obtained from Polygraph, Narco-analysis and Brain Electrical Activation Profile bear a testimonial character and they cannot be categorized as material evidence such as bodily substances and other physical objects. The Court accepted that while bodily substances such as blood, semen, sputum, sweat, hair and finger nail clippings as well as DNA profiling can be characterized as physical evidence, the same cannot be said about the techniques in question. The words "and such other tests" mentioned in Section 53 should be construed to include the examination of physical evidence but not that of testimonial acts.

Looking at the dictum laid down in various decisions, it is clear that though Section 53 of the code does not specifically provide for taking of blood sample for examination, yet there is no embargo for the Court under Section 53 of the Code to order for drawing blood sample for tests. The examination of a person under Section 53 of the Code cannot only be restricted to external examination but if necessary, would include examination of blood, urine and semen etc. Such an examination necessarily forms part of "investigation" as defined in Section 2(h) of the $\mathrm{Code}^{37}$.

A new clause, $53 \mathrm{~A}^{38}$, has been inserted by Amendment Act of 2005 to provide for a detailed medical examination of a person accused of an offence of rape or an attempt to commit rape

${ }^{36}$ Smt. Selvi v. State of Karnataka AIR 2010 SC 1974.

37 See also, Ritesh Sinha v. State of Uttar Pradesh AIR 2013 SC 1132.

38 Section 53A of the Code of Criminal Procedure 1973 reads as: Examination of person accused of rape by medical practitioner. - (1) When a person is arrested on a charge of committing an offence of rape or an attempt to commit rape and there are reasonable grounds for believing that an examination of this person will afford evidence as to the commission of such offence, it shall be lawful for a registered medical practitioner employed in a hospital run by the Government or by a local authority and in the absence of such a practitioner within the radius of sixteen kilometers from the place where the offence has been committed by any other registered medical practitioner, acting at the request of a police officer not below the rank of a sub-inspecttor, and for any person acting in good faith in his aid and under his direction, to make such an examination of the arrested person and to use such force as is reasonably necessary for that purpose.

(2) The registered medical practitioner conducting such examination shall, without delay, examine such person and prepare a report of his examination giving the following particulars, namely:-

(i) the name and address of the accused and of the person by whom he was brought,

(ii) the age of the accused,

(iii) marks of injury, if any, on the person of the accused,

(iv) the description of material taken from the person of the accused for DNA profiling, and".

(v) other material particulars in reasonable detail.

(3) The report shall state precisely the reasons for each conclusion arrived at.

(4) The exact time of commencement and completion of the examination shall also be noted in the report. 
by the registered medical practitioner. Such examination has been speciffied to include the details of the accused, the marks of injury, the materials taken from accused etc. Subsection (2) (iv) specifically provides for "the description of materials taken from the person of the accused for DNA profiling". "Cr.P.C (Amendment) Act, 2005 (25 of 2005) was introduced by the Legislature in order to overcome the difficulty in conducting the examination, i.e., examination of blood, blood stains, semen, swabs in the case of sexual offences, sputum and sweat; hair samples and finger nail clippings by the use of modern and scientific techniques including DNA profiling and such other tests which the registered medical practitioner thinks necessary in a particular case. As stated earlier, this amendment was brought to overcome the difficulty of the prosecuting agency to detect the serious offence of rape. This section is not ultra vires of the Constitution. Drawing of the blood sample for the purpose of civil proceedings without the consent of the party is not desirable. But drawing of the blood sample for detection of the offence of rape wherein the investigating agency has to establish its case beyond reasonable doubt, cannot be termed as violative of Article 20(3) of the Constitution. The offence of rape is a very serious offence and it is an offence against the society at large." 39

\subsection{Evidentiary Value}

DNA is not regarded as a conclusive piece of evidence, but can merely be an expert opinion used for the purposes of corroboration. The Indian Evidence Act 1872, makes provision for relevancy and admissibility of expert opinion ${ }^{40}$. An expert is a person who has devoted time and study to a special branch of learning, and thus is especially skilled on those points on which he is asked to state his opinion. There are no tests as such laid down by law to determine how much experience or qualification a person must possess to be taken as an expert $^{41}$. A combination of elements may be considered for accepting a witness as an expert, like:

(1) Expertise, including academic achievements, professional training, experience in the trade, means at the command and the application of those means for coming to a conclusion.

(2) Clarity, include avoidance of jargons, use of simple language, evidence supported by photographs, charts, sketches etc. so as to make his opinion appreciated by a layman.

(5) The registered medical practitioner shall, without delay, forward the report of the investigating officer, who shall forward it to the Magistrate referred to in section 173 as part of the documents referred to in clause (a) of sub-section (5) of that section.

39 Sri Halappa@Harthal Halappa v. State of Karnataka 2010 CriLJ 4341; Nem Singh v. State MANU/UP/0851/2013

40 Section 45 of the Indian Evidence Act 1872 reads as: When the Court has to form an opinion upon a point of foreign law, or of science, or art, or as to identity of hand writing or finger-impressions, the opinions upon that point of persons specially skilled in such foreign law, science or art, or in questions as to identity of handwriting or finger impressions, are relevant facts.

Such person called experts.

${ }^{41}$ Bhagwan R. Gawali, Dipa Dube, Expert Evidence-Admissibility and Appreciation with special reference to Ballistics, IJCMR Vol. 2 Issue 10 (2012) pp.1-6. 
(3) Relevancy, does not include mere presumption of facts, but drawing of conclusions either from his own experience or from published works of accredited authors.

Expert evidence is an "opinion evidence" and as a general rule, the opinion of a witness on a question of fact or of law is irrelevant. ${ }^{42}$ A witness may testify only to facts, not to their effect or result, or to use conclusions based on those facts and he can give evidence only of facts, which he has directly perceived through his senses. ${ }^{43}$ It is the function of the judge to form his own opinion on the facts stated. ${ }^{44}$ The opinion of witnesses possessing peculiar skills (as of experts) is an exception to this rule. ${ }^{45}$ It is important to note here that the opinion of an expert is not accepted just because he says so. He has to satisfy the court that his findings are unbiased and scientific. The duty of the expert witness is to furnish the judge with necessary scientific criteria for testing the accuracy of the conclusion so as to enable the judge to form his independent judgment by application of these criteria. ${ }^{46}$

The report of an expert is not admissible unless he has been examined as a witness and the party affected by it has had the opportunity of cross-examining him. Further, a finding by an expert not supported by reasons has to be rejected. ${ }^{47}$ Thus, the admissibility of an expert's evidence is subject to certain checks, which are in furtherance of the basic ideas of justice. "An expert witness is there neither for the prosecution nor for the defense, but is there to assist the court" should be sacredly espoused by the experts and an approach of caution should be taken up by the court. This basically means that the rule that "it is unsafe to base a conviction solely on the expert opinion without substantial corroboration" should be applied in all cases ${ }^{48}$ when an expert is giving evidence. Further, the testimony of an expert is to be received with great care and caution. ${ }^{49}$ It has been held by the courts that the expert evidence is a weak type of evidence that needs independent and reliable corroboration. ${ }^{50}$ Although there is no clear bar to base a conviction solely on expert evidence ${ }^{51}$, in the opinion of scholars, it is advisable not to base conviction solely on the opinion evidence "especially if the evidence were adduced is not supported by logical and scientific reasons." 52 One of the rules of caution that all courts follow as regards expert opinion is that they should never surrender their free will or independence or judgment to an expert. In all cases in which expert evidence is adduced before it, the Court must after giving it such weight as it deserves and the court thinks fit, make up its own mind upon the issue in respect of which the expert testimony has been given. ${ }^{53}$

\footnotetext{
${ }^{42}$ Khushboo Enterprises $\quad$ v. Forest Range Officer AIR 1994 SC 120

43 Babuli v. State 1973 CriLJ 510

44 MC Sarkar, SC Sarkar and PC Sarkar, Sarkar's Law of Evidence, Wadhwa and Company Law Publishers:

Nagpur, 1999, p.863.

45 Field, Commentary on Law of Evidence, Revised by Gopal S. Chaturvedi, Delhi Law House, 2001, p.2428

46 State v. Madhukar, 1967 Cri LJ 167.

47 State of Himachal Pradesh v. Jai Lal AIR 1999 SC 3318.

48 Haji Mohammad Ekramul Haq v. State of West Bengal AIR 1959 SC 488.

49 This basically means that the credit of an expert can be impeached like that of any other witness under Sections 146, 153 and 155 of the Indian Evidence Act, 1872.

50 Magan Bihari Lal v. State of Punjab 1977 Cri LJ 711

${ }^{51}$ S. Gopal Reddy v. State of Andhra Pradesh 1996 Cri LJ 3237.

${ }_{53}$ Murarilal v. State of MP AIR 1980 SC 531.

53 State of UP v. Krishna Gopal, 1989 Cri LJ 288.
} 


\section{Macrothink}

DNA evidence, therefore, can be considered as admissible under the Indian Laws as an expert opinion. It is placed in the same pedestal as other scientific or expert evidences and no special significance has been attached keeping in mind the accuracy, reliability and definiteness of its findings. As emphasized by the High Court in the case of Sabur Hossain Biswas v. State of West Bengal and Ors. ${ }^{54}$ :"Even it is assumed for the sake of argument that the DNA test becomes favourable to the petitioner that would not amount to absolving him of the charge under Section 376 of the IPC because the trial Court will have to consider the charge on the basis of the evidence of the prosecutrix and of other witnesses, if any and if the evidence of the prosecutrix and/or of any other witnesses supporting in the prosecutrix are found by the trial Court sufficient to indicate that offence under Section 376 of the IPC has been committed by the petitioner then the result of the DNA test by itself would be of no avail. Contra, if the oral evidence of the witnesses including that of prosecutrix are found to be not sufficient to hold the petitioner guilty of the charge of rape, then the result of the DNA test even if it would go to establish the paternity will equally be of no avail. Therefore it is not a deserving case where DNA test should be held."

The legal position in India may be stated thus: while a DNA examination may be conducted in course of investigation by the Police where it is of the opinion that the same will afford evidence of the commission of the offence, such evidence may be introduced in trial as expert evidence under Section 45 of the Act. The expert needs to convince the court of the modality of conduct, authenticity and accuracy of the findings based on his skill and knowledge of the subject. The Court may form an opinion based on the findings which, if the same appears probable in light of other evidences, the court may go on to accept.

\section{DNA Evidence in Rape Trials in India}

The use of DNA evidence in criminal trials in India is still at its infancy. Limited number of investigations utilize the procedure for the purposes of proving the offence. A study conducted in 2011 indicated that there were just 47 decisions during 2011 given by Supreme Court and different Indian High Courts in which the DNA sample played very important role. Most of the decisions were given by the Delhi High Court, i.e. 23.4 percent, while only 2.1 percent decisions given by six Indian High Courts. Of the cases, identification of persons and paternity issues were the ones where DNA was most resorted to, while for rapes, the use of DNA evidence was as low as $9.3 \%{ }^{55}$

\footnotetext{
542008 Crl.LJ 1183

${ }^{55}$ Nirpat Patel, Vidhwansh Gautaman, Shyam Sundar Jangir, The Role of DNA in Criminal Investigation- Admissibility in Indian Legal System and Future Perspectives, International Journal of Humanities and Social Science Invention, Vol. 2 (1), July 2013, pp.18-9.
} 
Table 1. Type of Case

\begin{tabular}{|c|l|c|c|}
\hline Sl No. & \multicolumn{1}{|c|}{ Type of Cases } & Frequency & Percent \\
\hline 1. & Murder & 2 & 4.7 \\
\hline 2. & Rape & 3 & 7.0 \\
\hline 3. & Rape with Murder & 1 & 2.3 \\
\hline 4. & Identification of Dead Body & 3 & 7.0 \\
\hline 5. & Identification of person & 17 & 39.5 \\
\hline 6. & Disputed Patemity & 15 & 34.9 \\
\hline 7. & Disputed Matemity & 2 & 4.7 \\
\hline & Total & 43 & 100.0 \\
\hline
\end{tabular}

Source: International Journal of Humanities and Social Science Invention, Vol. 2 (1), July 2013, p.19.

An analytical study of rape cases over the last decade has been conducted as part of the present study. A search for rape cases decided by the Supreme Court and all High Courts from 2002 to 2012 and 2013 has been made in the Indian Online Legal Database, Manupatra. The results yielded approximately 5300 reported decisions by the different courts of the country. The search was further narrowed down to cases where reference to the keyword 'DNA' has been made by the court. Around 160 cases were selected by the search machine in this category. A detailed study of each of these 160 cases was made. At the first instance, only cases which had been finally heard and decided by the Supreme Court or High Courts of the country were selected. Thereupon, the cases were classified on the parameters of use of forensic evidence, nature of forensic evidence and applicability of DNA test. While all the cases of rape had some form of medical evidence put on behalf of the prosecution, only few cases had utilized the technique of DNA. In the final selection of cases, three classifications were selected for the study: i) Where DNA had been conducted and accepted by Courts as evidence ii) where DNA had been conducted but not accepted by courts on certain grounds and iii) where DNA had not been conducted but the courts had referred to probable use of DNA by prosecution to prove the offence of rape. 42 cases were finally selected for the purposes of the study.

\section{Preliminary Points}

The scope and applicability of DNA evidence in very limited in cases of rape in India. As already discussed, it is a corroborative piece of evidence, which is introduced as expert opinion in individual cases. DNA, for all reasons, can never supplant the eye witness or other oral testimonies which may be available in a case, but it definitely supplements the available evidence and establishes with accuracy the identity of the offender/s in a rape case. Such identity becomes crucial in two situations of rape: one, in case of statutory rapes concerning minors $^{56}$, the issue of consent of the girl is immaterial for the purposes of establishing the offence and DNA evidence may help to establish the offender; and secondly, DNA becomes significant in case of stranger-only rapes, otherwise known as 'classic rapes ${ }^{, 57}$. There are other

\footnotetext{
${ }^{56}$ Section 375 Sixthly, Indian Penal Code 1860 reads as: With or without consent, when she is under eighteen years of age.

${ }^{57}$ Classic rape has been described as the stereotypical rape situation: a woman is suddenly and violently attacked by a stranger. Identification of the perpetrator is usually a problem in this type of case, as opposed to a date rape situation where the victim knows her assailant.
} 


\section{Macrothink}

forms of rape like date rapes, acquaintance rapes etc. where the evidence of DNA may be relevant but not crucial for the purposes of establishing liability, the offender being known to the victim in such cases. With these preliminary points in mind, the applicability of DNA evidence in Indian situation may be analyzed.

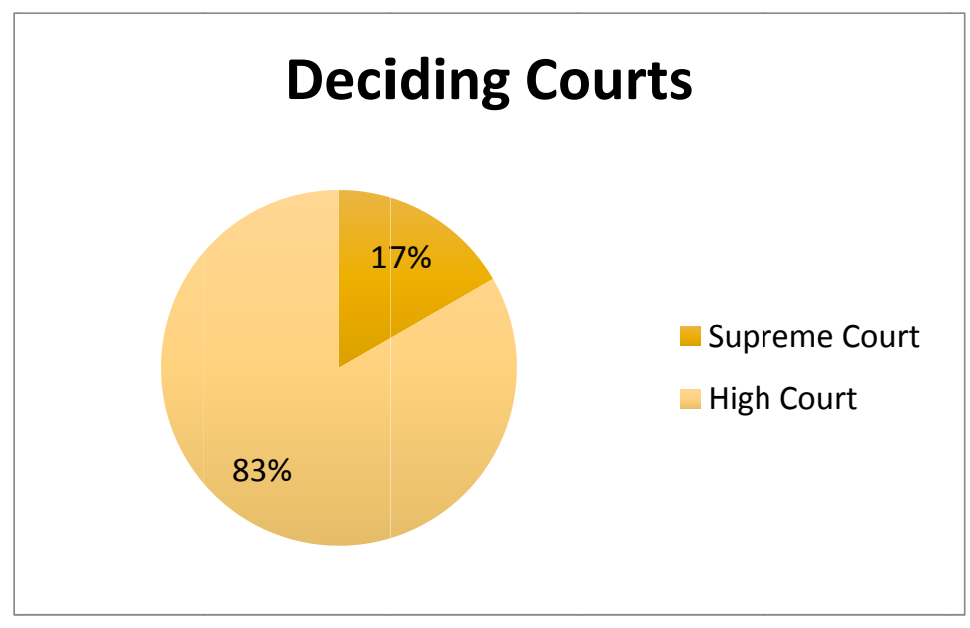

Figure 7.1 Deciding Courts

Of the cases selected, there are seven cases decided by the Supreme Court and 35 cases of the different High Courts of the country. Efforts have been made to include cases of all High Courts, so far as possible. Cases have been taken from all the years ranging from 2002 to 2013. Thus, there are 10 cases of 2013, 6 each of 2012 and 2011, 1 case of 2010, 3 cases of 2009, two cases of 2008 , seven cases of 2007 and so on.

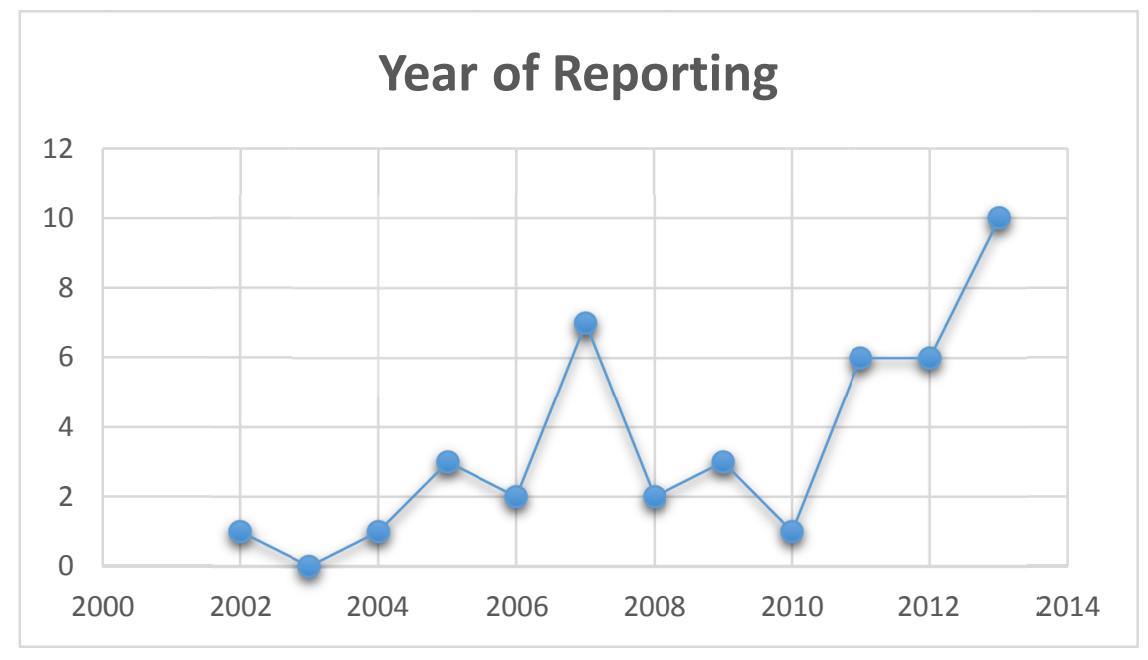

Figure 7.2 Year of Reporting

While all decided cases are of the offence of rape, there are some which have other offences in addition thereto, like murder, criminal intimidation, robbery etc. 


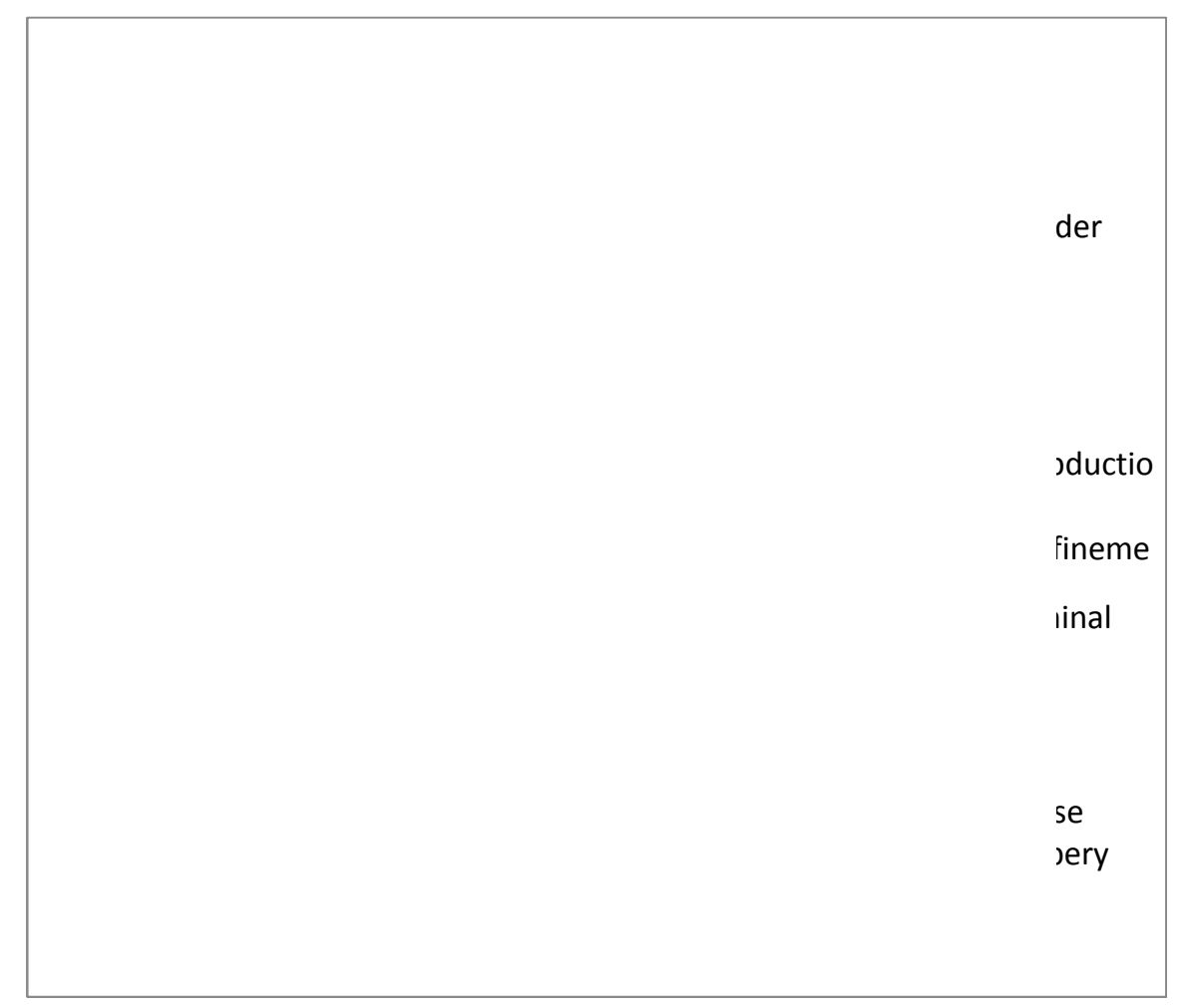

Figure 7.3 Nature of Offence

Of the 42 select cases, DNA was conducted in about 26 cases, while in 16 cases no such test was conducted. However, in each of the 16 cases, Court has referred to the scientific advancement in recent years and the possibility of adducing clinching evidence in the form of DNA reports to establish the guilt of the accused. It may, however, be remembered that all the 16 cases did not result in acquittal of the accused. The Courts have relied on oral evidence of the victim, witnesses, extra judicial confessions, medical reports etc. to bring home the guilt of the accused. Nevertheless, the courts have reiterated that a DNA test could have made matters easy and buttress the case for the prosecution.

Interestingly, in five cases, even though DNA was conducted, the same was not either produced by the prosecution or relied upon by the Courts. In the former category, the Court could easily deduce that the non-production of the DNA report was a sort of manipulation on the part of the prosecution to suppress the truth ${ }^{58}$. In the latter category, there are cases where there are conflicting DNA reports. The taking of samples, sealing, transportation to the laboratories, storage and finally, the conduct of the test have to be done according to certain accepted standards. However, in these cases the Courts have found that the experts have been unable to satisfy the Court of the methods of preservation of sample used by the lab or the instrument used and processes involved yielded "absurd" and "confounding" results. "The collection of blood was thus admittedly defective, and coupled with the conflicting and confusing results of the DNA report presented enough justification for the trial Court to reject

58 State of Haryana v. Rewa Singh MANU/PH/1164/2002. 


\section{Macrothink}

both the DNA reports. ${ }^{, 59}$ In other two cases, the Court refused to place reliance on the DNA thereby acquitting the accused in one case and convicting him in the other. In the former ${ }^{60}$, the court emphasized that in the absence of motive, the accused could not be hell guilty of rape and murder of the child victim; in the next case, the court held that oral testimony was credible and no further evidence was required in the form of DNA, since in the instant case the DNA did not establish any link of the accused with the alleged offence.

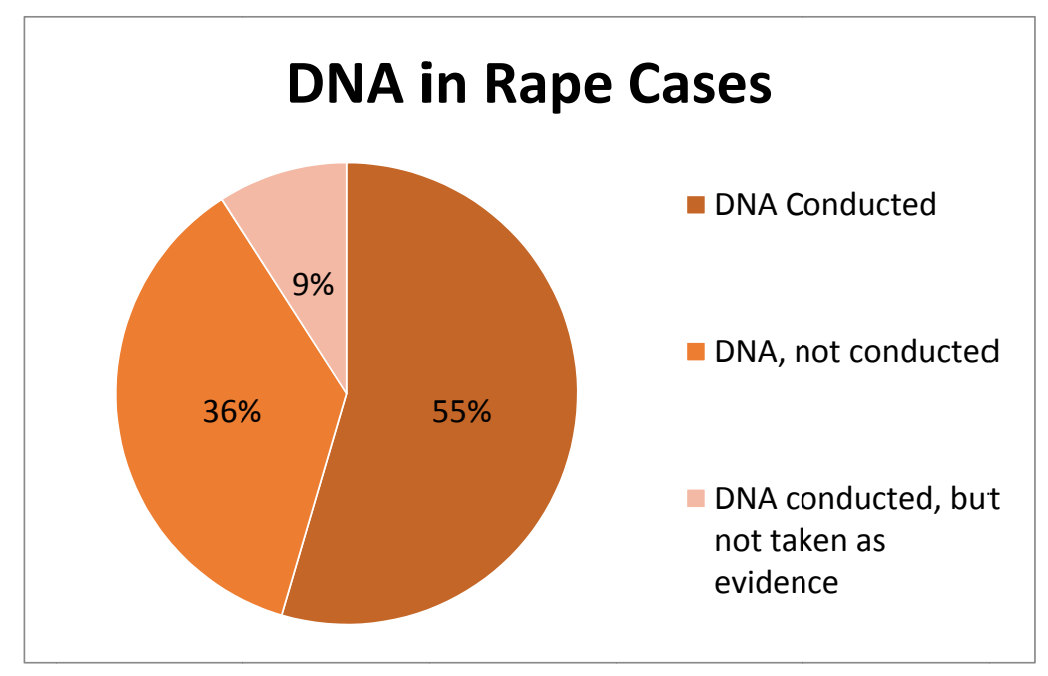

Figure 7.4 Use of DNA in Rape Cases

A study of the cases indicate that there has been mixed results with regard to introduction of DNA evidence in rape cases. Of the 42 cases, near about 17 cases strongly relied on DNA to establish the guilt of the accused while, in another three cases, the accused could be safely exonerated of the crime based on the DNA report. As stated by the court in Raghuvir Dessai v. State ${ }^{61}$ the DNA testing hits the nail on the head of the accused and is the last and clinching piece of evidence which shows that it is the accused and the accused alone who committed the rape on the victim. The conviction of the accused, therefore, could not be faulted in the light of overwhelming evidence produced by the prosecution. Again in Chotu v. State of Rajasthan ${ }^{62}$, the Court emphasized that DNA Test is almost a full proof method of identifying the culprit. The sophisticated technology makes it possible to obtain conclusive results. ${ }^{63}$

In the absence of DNA results, the court has acquitted the accused in 12 cases because according to the court "the investigating agency and the FSL ought to have carried out DNA test of the blood belonging to the accused as well as the victim so as to ascertain whether blood of the victim was in fact on the clothes of the accused. Had such an effort been made by the prosecution, the outcome of the said effort would have helped a lot to the trial court in ascertaining whether the accused had in fact visited the scene of offence. The DNA profiling

\footnotetext{
${ }^{59}$ Hari Shankar Tewari v. State of Tripura 2005 CriLJ 3323.

${ }^{60}$ Ashish Mandal v. State MANU/MH/0630/2008.

612007 CriLJ829.

62 2006(17)CriminalCC231

63 Thogorani alias K. Damayanti v. State of Orissa and Ors. 2004CriLJ4003
} 
could have given a clear picture ... It is really deplorable that in spite of so much of advancement in the field of forensic science, the investigating agency did not think it proper to resort to DNA test, and stopped the investigation just by getting the blood classified as per ABO method." 64 However, the absence of DNA evidence has made no difference in the judgments of the courts in about 9 cases where the latter have expressed the opinion that the evidence otherwise available is clear and cogent and do not leave any room for doubt as regards the culpability of the accused.

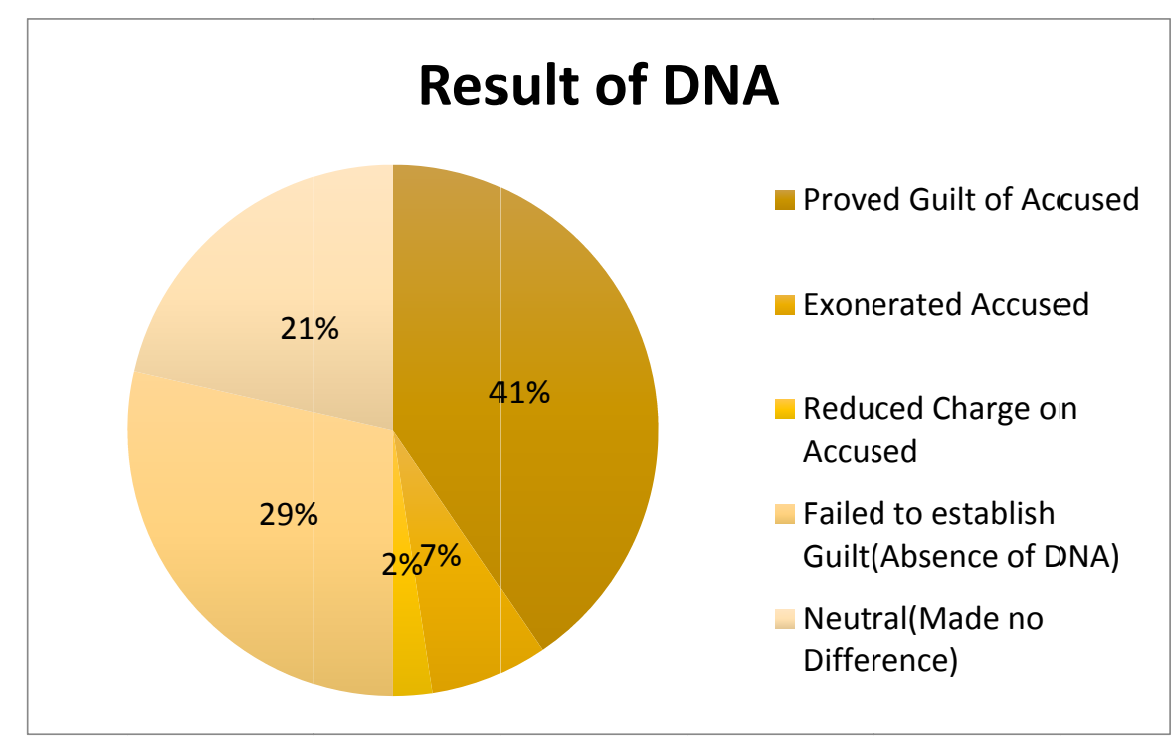

Figure 7.5 Decisions of Court

An overall analysis of the decided cases helps us to establish certain analogies:

i) Cases based on oral evidence when coupled with the corroborative evidence in the form of DNA help the court to reach definitive conclusion of the guilt of the accused $^{65}$.

ii) Cases based entirely on oral evidence and medical evidence but no DNA generates $50 \%$ chance of the accused being convicted or acquitted. The reason being that the courts have to decipher the credibility of the victim and whether her testimony inspires confidence ${ }^{66}$.

iii) Cases essentially based on circumstantial evidence greatly relies on DNA for the purposes of decision making ${ }^{67}$.

\footnotetext{
${ }^{64}$ State of Gujarat v. Kishanbhai S/o Velabhai Vanabhai Marwadi MANU/GJ/0506/2005

65 Vinay Kr. Singh v. State 2012 (4) JCC 2857; Sant Ram v. State 2013 VI AD (Delhi) 439; Subhash Swami Naik v. State of Goa $\mathrm{Manu} / \mathrm{MH} / 0028 / 2007$ (For more, see Appendix).

${ }^{66}$ Krishan Kr. Mallick v. State of Haryana AIR 2011 SC 2820; Rupeshwar Tanti v. State of Assam 2012 CrLJ 2549; Indramani Thapliyal v. State of Uttarakhand 2013 CrLJ 3027 (For more, see Appendix).

${ }^{67}$ Laxman v. State of Chattisgarh 2012 (4) CGLJ 338; Santosh Kr. Singh v. State 2010 (4) Crimes 226 (SC); State v. Jyotish Prasad Manu/DE/0999/2009; In. Ref. v. Rajesh \& Anr. Manu/MP/1834/2013 (For more, see Appendix).
} 


\section{MInstitute Macrothink}

iv) In cases of gang rapes, DNA is a crucial piece of evidence to establish the links of the accused to the crime in question ${ }^{68}$.

v) In cases where the offence has led to child birth, DNA is significant to establish the paternity of the child and thereby the links of the accused to the alleged crime in question $^{69}$.

vi) In rapes of minor girls (or statutory rapes), DNA is the single piece of evidence which can help to establish the violation of the victim by the accused, thereby establishing guilt, in the absence of the requirement of consent on her part ${ }^{70}$.

The study of the cases over the last decade reveals that DNA is increasingly being used as evidence in rape trials over the years. Infact, as compared to 2002, in the years 2012 or 2013, we find more and more cases coming up before the courts where, in addition to oral and medical evidence, DNA examination is being used by investigation to prove the fact of sexual assault. The Courts are also receptive of DNA evidence as is clear from several cases of acquittal where the courts have emphasized that probably DNA could have helped to establish the missing links in the crime in question. In Rewa Ram Sahu v. State ${ }^{71}$, the court has said that after the incorporation of Section 53A Code of Criminal Procedure, 1973, DNA test in each and every case has become compulsory. Echoing a similar sentiment, the Delhi Sessions Court recently lamented that even though DNA has been included in the Code, the procedure is still not being followed. The court noted that many investigators still opt for the old methods of blood grouping, which makes it hard to establish the liability of the accused. "It has therefore become necessary for investigating agencies and also for the State to ensure that in cases of sexual assault, particularly those involving gang rape, or where the identity of the accused is not known to the victim, or where the victim is a child, DNA profiling is made mandatory. I am hopeful that with due intervention of senior officers of State and Police, the existing scientific technology shall be put to its best utilization, so as to ensure that the guilty are not let off and the innocent do not suffer. ${ }^{72}$

\section{Limitations}

However, inspite of this encouraging trend, the numbers are still abysmally low and concerted efforts need to be made to include DNA evidence in all cases, as reiterated above. There appears to be some lacuna in this regard, as is apparent from the cases under scrutiny. First, lack of infrastructure appears to be a roadblock with thousands of rape cases piling up over the years. There are few laboratories and diagnostic centers in India with the requisite facilities to conduct DNA tests. All States have to rely on these labs to conduct the test and hence,

\footnotetext{
${ }^{68}$ Krishan Kr. Mallick v. State of Haryana AIR 2011 SC 2820; Vinay Kr. v. State 2012 (4) JCC 2857; Ajit Burman v. State of West Bengal 2007 (3) CHN 747(For more, see Appendix).

69 Soundarrajan v. State of Tamil Nadu MANU/TN/ 8839/2007; Sant Ram v. State 2013 VI AD (Delhi) 439; Kamalanantha \& Ors. v. State of Tamil Nadu 2007 SC 2132; Jayavelu v. State Manu/TN/2604/2009 (For more, see Appendix).

${ }^{70}$ Kamalanantha \& Ors.v.State of Tamil Nadu 2007 SC 2132; Gilbert v. Kerala 2012 (1) KLJ 239; Anandamay Bag v. State of West Bengal 2007(4)CHN470.

71 2012(4) CGLJ 464

72 Jayant Sriram, DNA testing mandatory in all rape cases, says courts, Indian Express Online Edition, Jan 29, 2012 Available at http://www.indianexpress.com/news/dna-testing-mandatory-in-all-rape-cases-says-court/905091/ Accessed on $11^{\text {th }}$ Nov, 2013.
} 
investigation is seriously affected and a huge delay sets in. "Courts cannot deprive the accused and victim from their constitutional rights on the mere ground that FSL is overburdened. If state thinks that FSL is overburdened, it is the duty of the state to set up sufficient infrastructure. Such excuses cannot prolong the trial." Saying so, the Sessions Court levied Rs. 10000 as fine on the Delhi Government and pulled up the police and Forensic Science Lab for failing to submit the DNA even after 15 months. ${ }^{73}$ Furthermore, it may be noted that DNA tests involve certain costs and therefore, on many occasions the investigation refrains from resorting to it. The same is clear from the case of rape and murder of a child, where the Circle Inspector reported to the Court that "he had requested the higher authorities for sanctioning a sum of Rs.20,000/- which was the amount to be remitted at the Rajiv Gandhi Centre for Biotechnology for conducting DNA finger printing test, but the amount was not sanctioned."74 The Court thus remarked that "It is really unfortunate that even when such a gruesome rape-cum-murder was committed, the Government/Police Department could not raise a sum of Rs. 20,000/-. ... had the victim been of a rich or powerful class, then the Government would have spent any amount for such purposes, but only because the victim happened to be of a very poor family, the authorities turned deaf ear to the genuine request made by P.W.38 for sanctioning a sum of Rs. 20,000/-."

Secondly, the lack of trained manpower to deal with DNA proves to an obstacle in this regard. As stated by Dr. G.K. Goswami ${ }^{75}$, DNA profiling is a complex scientific procedure and its success lies in the skill and expertise of the Investigation Officer who is the first player to handle the "sample" and if he fails to do so, the whole exercise of diagnostic center goes waste. He further elucidates that the role of the Investigation Officer is crucial in each of the stages of handling the sample, namely, collection or lifting the sample, preservation, sealing, packaging, labeling, storage, docketing through court, maintaining chain of custody, transport to appropriate diagnostic center. The Investigation Officer is required to testify before the court with regard to the correctness and propriety of procedure followed but, in the absence of appropriate training and expertise, in many situations results turn disastrous.

Thirdly, procedures adopted at the level of the scientific laboratories should be standardized and uniform processes should be adopted in DNA probing to rule out possibilities of ambiguity or improper results. As is clear from few cases stated above, the courts could not safely rely on the DNA reports either because of contradictions, or absurd conclusions. Insufficient samples, improper methods of preservation, inordinate delays in examination, non-functionality of instruments etc. have been found to be major blocks in relying on the DNA evidence in courts. Furthermore, "The expert witness is expected to put before the Court all materials inclusive of the data which induced him to come to the conclusion and enlighten the Court on the technical aspect of the case by explaining the terms of science so that the Court although, not an expert, may form its own judgment on those materials after giving due regard to the expert's

\footnotetext{
73 Aneesha Mathur, FSL delays DNA report in rape case, govt. fined Rs. 10000, Indian Express Online Edition, Sept 23, 2013 Available at http://www.indianexpress.com/news/fsl-delays-dna-report-in-rape-case-govt-fined-rs-10000/1172778/ Accessed on $2^{\text {nd }}$ Nov 2013.

${ }_{74}$ Gilbert v. Kerala 2012 (1) KLJ 239.

75 Dr. G.K. Goswami, Legal Issues related to DNA Fingerprinting in Criminal Justice System, Available at http://goswamigk.indianscholars.org/2011/03/legal-issues-related-to-dna-fingerprinting-in-criminal-justice-system/ Accessed on $2^{\text {nd }}$ Nov 2013.
} 
opinion". ${ }^{76}$ Adequate legal knowledge, in addition to technical expertise, will help the experts to clarify the doubts raised in course of the testimony.

Lastly, adequate awareness and knowledge may be generated amongst the judicial community to appreciate the nuances of DNA technology. At times, it has been seen that the Courts are quick to ignore the DNA reports in light of other evidences. Thus, conduct of parties, motive, contradiction in statements etc. have more relevance and weightage before the court than scientific conclusions. Sadly, however, while the former is fallible, the latter is infallible and precise. The Courts are expected to garner themselves to the advances posed by science and its rightful intervention in administration of justice.

\section{Conclusion}

The offence of rape has become the greatest challenge for the law enforcement today. The overwhelming number of incidents has triggered a search for new and innovative measures for prevention, detection, investigation and trial of the offence. DNA technology is a partial answer to the problem and may go a long way in upholding justice for the victims. As an invaluable asset in the positive identification of perpetrators, the use of DNA fingerprinting tests help to greatly improve the probability of successful prosecutions. As the same time, it also holds the key to exculpate those who have been falsely accused.

DNA has been hailed as "the scientific hero" of the contemporary times, a form of scientific triumphalism, where science thwarts human prejudices ${ }^{77}$. The scientific objectivity and validity associated with DNA evidence is important to criminal investigations because it is believed to remove the "guesswork" out of decisions of guilt or innocence. A study of decisions by Indian courts reveal that DNA is still at its infancy in its application to Criminal Justice, more specifically, the offence of rape. The legal position has been well clarified by the apex court to indicate that the examination does not violate the constitutional guarantees of life or self-incrimination, and the procedural laws makes it mandatory to conduct DNA in allegations of rape. Even then, investigation has not made use of the facility in majority of cases, while in few others, the Courts have not attached sufficient significance to the same. In the limited number of cases where DNA evidence has been introduced as expert opinion, the courts have indicated a mixed trend, with $29 \%$ cases relying on the DNA alongwith other evidences for the purpose of decision making while another $21 \%$ cases preferring to keep aside the results. Infact, in the absence of any relevant statute with regard to admissibility of DNA tests, the court has to determine that appropriate standards have been followed, the test has been adequately performed by a reliable laboratory and appropriate protocols for DNA typing and formulation of an opinion have been complied with. Certain lacunas in this regard have come to the fore, as is well understood from the case laws analysed above. The lack of infrastructure, trained manpower, standardised procedures and maybe to some extent, judicial maladroitness impedes the entire process. It is imperative that effective steps are taken by the State to address the critical issues as DNA beams the ray of hope for an improved Criminal Justice system.

\footnotetext{
${ }_{76}^{76}$ Madan Gopal Kakkad v. Naval Dubey JT1992 (3)SC 270.

77 Jenny Wise, The New Scientific Eye Witness, University of New South Wales, Doctoral Thesis, 2008.
} 


\section{Acknowledgement}

This paper has been presented at the International Conference of Forensic Science and Criminalistics Research, December, 2013 at Singapore and an abstract published in the Book of Abstracts. The paper has been substantially modified and improved since the first version.

\section{Appendix}

\begin{tabular}{|c|c|c|c|c|c|c|c|c|}
\hline \multicolumn{9}{|c|}{$\begin{array}{l}\text { DNA Evidence in Rape Cases- Judicial decisions (2002-2012 \& 2013) } \\
\text { Summary of Cases }\end{array}$} \\
\hline $\begin{array}{l}\text { Sl } \\
\text { No. }\end{array}$ & Case & Citation & Offence & $\begin{array}{l}\text { Nature of } \\
\text { Evidence }\end{array}$ & \begin{tabular}{|l|} 
DNA \\
Evidence \\
conducted \\
\end{tabular} & \begin{tabular}{|l|} 
Decision of \\
Trial \\
Court \\
\end{tabular} & \begin{tabular}{|l|} 
Decision of High \\
Court/Supreme \\
Court \\
\end{tabular} & $\begin{array}{l}\text { Rel. of DNA } \\
\text { Evidence, if any }\end{array}$ \\
\hline 1 & $\begin{array}{l}\text { Soundarrajan v. } \\
\text { State of Tamil } \\
\text { Nadu }\end{array}$ & MANU/TN/ 8839/2007 & Rape & $\begin{array}{l}\text { Oral Evidence, } \\
\text { Forensic Evidence }\end{array}$ & $\begin{array}{l}\text { Yes; of still } \\
\text { born child } \\
\text { of victim }\end{array}$ & Convicted & Acquitted & $\begin{array}{l}\text { Yes; DNA estb the } \\
\text { accused did not } \\
\text { father the child }\end{array}$ \\
\hline 2 & $\begin{array}{l}\text { Krishan Kr. } \\
\text { Mallick v. State } \\
\text { of Haryana }\end{array}$ & AIR 2011 SC 2820 & $\begin{array}{l}\text { Gang Rape } \\
\& \\
\text { Kidnapping }\end{array}$ & $\begin{array}{l}\text { Oral Evidence, } \\
\text { Forensic Evidence }\end{array}$ & No & \begin{tabular}{|l|}
\multicolumn{2}{|l|}{ Convicted; } \\
One in \\
appeal to \\
SC
\end{tabular} & Acquitted & $\begin{array}{l}\text { Inconsistent } \\
\text { Statement of Victim; } \\
\text { No DNA conducted } \\
\text { which failed to prove } \\
\text { the allegation }\end{array}$ \\
\hline 3 & $\begin{array}{lll}\text { Vinay } & \mathrm{Kr} . \mathrm{v} . \\
\text { State }\end{array}$ & 2012 (4) JCC 2857 & $\begin{array}{l}\text { Murder \& } \\
\text { Rape }\end{array}$ & $\begin{array}{l}\text { Oral Evidence, } \\
\text { Recovery of Stolen } \\
\text { Items and DNA }\end{array}$ & Yes & Convicted & $\begin{array}{l}\text { One Convicted } \\
\text { and the other } \\
\text { accused acquitted }\end{array}$ & $\begin{array}{l}\text { Yes; DNA evidence } \\
\text { estb. the culpability } \\
\text { of one accused and } \\
\text { helped to exonerate } \\
\text { the other }\end{array}$ \\
\hline 4 & $\begin{array}{ll}\text { Laxman } & v . \\
\text { State } & \text { of } \\
\text { Chattisgarh } & \end{array}$ & 2012(4)CGLJ 338 & $\begin{array}{l}\text { Murder } \& \\
\text { rape }\end{array}$ & $\begin{array}{l}\text { Circumstantial } \\
\text { Evidence }\end{array}$ & No & Convicted & Acquitted & $\begin{array}{l}\text { Extrajudicial } \\
\text { confession } \\
\text { inadequate; no DNA } \\
\text { hence inconclusive } \\
\text { results }\end{array}$ \\
\hline 5 & $\begin{array}{lll}\text { Sant } & \text { Ram } & \text { v. } \\
\text { State } & & \end{array}$ & 2013 VI AD (Delhi) 439 & $\begin{array}{l}\text { Rape \& } \\
\text { Criminal } \\
\text { Intimidation }\end{array}$ & $\begin{array}{l}\text { Oral evidence, } \\
\text { Forensic evidence }\end{array}$ & $\begin{array}{l}\text { Yes; of } \\
\text { victim, } \\
\text { accused and } \\
\text { child born }\end{array}$ & Convicted & Convicted & $\begin{array}{l}\text { DNA estb. The } \\
\text { matching link; } \\
\text { reliable testimony }\end{array}$ \\
\hline 6 & $\begin{array}{l}\text { State of H.P. v. } \\
\text { Ramesh Kumar }\end{array}$ & MANU/HP/1914/2011 & $\begin{array}{l}\text { Murder \& } \\
\text { Rape }\end{array}$ & $\begin{array}{l}\text { Extra Judicial } \\
\text { confession }\end{array}$ & Yes; & Acquitted & $\begin{array}{l}\text { One Convicted } \\
\text { and the other } \\
\text { accused acquitted }\end{array}$ & $\begin{array}{l}\text { Yes; on the basis of } \\
\text { DNA, the court could } \\
\text { conclusively } \\
\text { establish the } \\
\text { culpability of one in } \\
\text { both the rape and } \\
\text { murder, while the } \\
\text { absence of match } \\
\text { with the other } \\
\text { accused exonerated } \\
\text { him. }\end{array}$ \\
\hline 7 & $\begin{array}{l}\text { State v. Jyotish } \\
\text { Prasad \& Anr. }\end{array}$ & MANU/DE/0999/2009 & $\begin{array}{l}\text { Murder, } \\
\text { Rape, } \\
\text { Robbery }\end{array}$ & $\begin{array}{l}\text { Circumstantial } \\
\text { Evidence }\end{array}$ & Yes; & Convicted & Convicted & \begin{tabular}{|lr} 
Yes; entire reliance \\
placed on DNA \\
evidence & for \\
conviction & \\
\end{tabular} \\
\hline 8 & $\begin{array}{l}\text { Kabhaibhai } \\
\text { Deshaibhai } \\
\text { Rathod v. State } \\
\text { of Gujrat }\end{array}$ & MANU/GJ/7011/2007 & \begin{tabular}{|l} 
Rape, \\
Criminal \\
Intimidation
\end{tabular} & Oral Evidence & No & Convicted & Acquitted & $\begin{array}{l}\text { No DNA to link the } \\
\text { accused to the crime; } \\
\text { delay in lodging } \\
\text { case; victim turning } \\
\text { hostile }\end{array}$ \\
\hline 9 & $\begin{array}{l}\text { State of Kerala } \\
\text { v. M. Ayoob }\end{array}$ & 2005 (2) KLT 441 & Rape & Oral Evidence & No & Acquitted & Convicted & $\begin{array}{l}\text { Oral Testimony } \\
\text { credible; Judge noted } \\
\text { that DNA would } \\
\text { have further helped } \\
\text { in the matter. }\end{array}$ \\
\hline 10 & $\begin{array}{l}\text { Rupeshwar } \\
\text { Tanti v. State of }\end{array}$ & 2012 Cr.L.J. 2549 & Rape & Oral Evidence & No & Convicted & Acquitted & $\begin{array}{ll}\text { Oral testimony } & \text { non } \\
\text { credible; } & \text { Not }\end{array}$ \\
\hline
\end{tabular}




\begin{tabular}{|c|c|c|c|c|c|c|c|c|}
\hline & Assam & & & & & & & $\begin{array}{l}\text { believed by Court in } \\
\text { absence of DNA }\end{array}$ \\
\hline 11 & $\begin{array}{l}\text { Subhash Swami } \\
\text { Naik v. State of } \\
\text { Goa }\end{array}$ & MANU/MH/0028/2007 & Rape & $\begin{array}{l}\text { Oral Evidence, } \\
\text { Forensic Evidence }\end{array}$ & Yes & Convicted & Convicted & $\begin{array}{l}\text { Oral Testimony and } \\
\text { DNA evidence } \\
\text { cogent and reliable }\end{array}$ \\
\hline 12 & \begin{tabular}{|ll} 
Baphira & \\
Kharkongar & $\mathrm{v}$. \\
State & of \\
Meghalaya & \\
\end{tabular} & 2009 (4) GLT 293 & $\begin{array}{l}\text { Rape, } \\
\text { Wrongful } \\
\text { Restraint }\end{array}$ & $\begin{array}{l}\text { Oral Evidence, } \\
\text { Forensic Evidence }\end{array}$ & Yes & Convicted & Convicted & $\begin{array}{l}\text { DNA crucial to } \\
\text { establish the number } \\
\text { of accused }\end{array}$ \\
\hline 13 & \begin{tabular}{|l} 
Jarnail Singh v. \\
State of \\
Himachal \\
Pradesh \\
\end{tabular} & 2013 (1) Crimes 158 & Rape & $\begin{array}{l}\text { Oral Evidence; } \\
\text { Forensic Evidence }\end{array}$ & Yes & Convicted & Convicted & $\begin{array}{l}\text { Oral Testimony } \\
\text { coupled with DNA } \\
\text { match reliable. }\end{array}$ \\
\hline 14 & $\begin{array}{l}\text { Ajit Burman v. } \\
\text { State of West } \\
\text { Bengal }\end{array}$ & 2007(3) CHN 747 & $\begin{array}{l}\text { Rape and } \\
\text { House } \\
\text { Trespass }\end{array}$ & $\begin{array}{l}\text { Oral Evidence; } \\
\text { Forensic Evidence }\end{array}$ & Yes & Convicted & Convicted & \begin{tabular}{|lr} 
Oral & Evidence \\
credible; & DNA \\
crucial to establish \\
the number of \\
persons \\
\end{tabular} \\
\hline 15 & \begin{tabular}{|l} 
Bandari \\
Gangaram v. \\
State of AP \\
\end{tabular} & 2011 CRiLJ4430 & $\begin{array}{l}\text { Rape and } \\
\text { Criminal } \\
\text { Intimidation }\end{array}$ & $\begin{array}{l}\text { Oral Evidence; } \\
\text { Forensic Evidence }\end{array}$ & Yes & Convicted & Convicted & Evidence credible. \\
\hline 16 & $\begin{array}{l}\text { Chandrakant } \\
\text { Vithal Pawar v. } \\
\text { State of } \\
\text { Maharashtra } \\
\end{array}$ & MANU/MH/1826/2011 & $\begin{array}{l}\text { Rape, } \\
\text { Kidnapping } \\
\text { and Hurt }\end{array}$ & $\begin{array}{l}\text { Oral Evidence; } \\
\text { Forensic Evidence }\end{array}$ & Yes & Convicted & $\begin{array}{lr}\text { Convictied } & \text { but } \\
\text { Reduced } & \text { to } \\
\text { Attempt } & \end{array}$ & $\begin{array}{l}\text { DNA and other } \\
\text { forensic evidence } \\
\text { partially relied upon }\end{array}$ \\
\hline 17 & \begin{tabular}{|l} 
Indramani \\
Thapliyal v. \\
State of \\
Uttarakhand \\
\end{tabular} & 2013 CriLJ 3027 & Rape & Oral Evidence & No & Convicted & Convicted & $\begin{array}{l}\text { Absence of DNA } \\
\text { significant }\end{array}$ \\
\hline 18 & $\begin{array}{l}\text { Ramnaresh \& } \\
\text { Ors. v. State of } \\
\text { Chattisgarh }\end{array}$ & AIR 2012 SC 1357 & $\begin{array}{l}\text { Rape, } \\
\text { Murder and } \\
\text { House } \\
\text { Trespass } \\
\end{array}$ & $\begin{array}{l}\text { Oral Evidence; } \\
\text { Incomplete } \\
\text { forensic Report }\end{array}$ & No & Convicted & Convicted & Evidence credible. \\
\hline 19 & $\begin{array}{l}\text { Surendra Koli } \\
\text { v. State of UP }\end{array}$ & AIR 2011 SC 970 & $\begin{array}{l}\text { Rape. } \\
\text { Murder and } \\
\text { Kidnapping } \\
\end{array}$ & $\begin{array}{l}\text { Oral Evidence, } \\
\text { Forensic evidence }\end{array}$ & Yes & Convicted & Convicted & $\begin{array}{l}\text { Evidence Cogent and } \\
\text { credible }\end{array}$ \\
\hline 20 & $\begin{array}{l}\text { Santosh Kr. } \\
\text { Singh v. State }\end{array}$ & $2010(4)$ crimes $226(\mathrm{SC})$ & $\begin{array}{l}\text { Rape, } \\
\text { Murder }\end{array}$ & $\begin{array}{l}\text { Circumstantial } \\
\text { Evidence }\end{array}$ & Yes & Convicted & Convicted & \begin{tabular}{|l} 
Evidence Credible; \\
DNA estb the \\
complicity \\
accused
\end{tabular} \\
\hline 21 & $\begin{array}{l}\text { Vijayan v. State } \\
\text { of kerala }\end{array}$ & (2008) 14 SCC 763 & Rape & Oral Evidence & No & Convicted & Acquitted & $\begin{array}{l}\text { No DNA, reliance } \\
\text { can't be placed solely } \\
\text { on victim testimony }\end{array}$ \\
\hline 22 & $\begin{array}{l}\text { Kamalanantha } \\
\text { \& Ors. V. State } \\
\text { of Tamil Nadu }\end{array}$ & 2007 SC 2132 & Rape & $\begin{array}{l}\text { Oral Evidence, } \\
\text { Forensic Evidence }\end{array}$ & Yes & Convicted & Convicted & $\begin{array}{l}\text { Yes, helped to } \\
\text { establish paternity } \\
\text { with accused }\end{array}$ \\
\hline 23 & $\begin{array}{l}\text { State of Gujrat } \\
\text { v. Kishanbhai } \\
\text { Marwadi } \\
\end{array}$ & Manu/GJ/0506/2005 & $\begin{array}{ll}\text { Rape } \quad \& \\
\text { Murder }\end{array}$ & Oral Evidence & No & Convicted & Acquitted & $\begin{array}{l}\text { Yes, DNA evidence } \\
\text { could have helped to } \\
\text { prove the guilt }\end{array}$ \\
\hline 24 & \begin{tabular}{|ll} 
State & of \\
Rajasthan & $\mathrm{v}$. \\
Ram Niwas &
\end{tabular} & 2006 CriLJ 2477 & $\begin{array}{l}\text { Rape, } \\
\text { Murder, } \\
\text { Abduction }\end{array}$ & Oral Evidence & No & Acquitted & Acquitted & $\begin{array}{l}\text { Yes, absence of clear } \\
\text { and cogent evidence, } \\
\text { No DNA to link the } \\
\text { accused to the crime }\end{array}$ \\
\hline 25 & $\begin{array}{l}\text { Raghubir Desai } \\
\text { v. State }\end{array}$ & 2007 Cri LJ 829 & $\begin{array}{l}\text { Rape and } \\
\text { wrongful } \\
\text { confinement }\end{array}$ & $\begin{array}{l}\text { Oral evidence, } \\
\text { Forensic evidence }\end{array}$ & Yes & Convicted & Convicted & $\begin{array}{l}\text { Yes, DNA taken as } \\
\text { last and clinching } \\
\text { piece of evidence to } \\
\text { establish guilt }\end{array}$ \\
\hline 26 & $\begin{array}{l}\text { Vikram Singh } \\
\text { v. State of } \\
\text { Haryana }\end{array}$ & 2007 CRiLJ 1077 & $\begin{array}{l}\text { Rape, } \\
\text { Murder, } \\
\text { Trespass, } \\
\text { Robbery }\end{array}$ & $\begin{array}{l}\text { Circumstantial } \\
\text { EvidenceForensic } \\
\text { Evidence }\end{array}$ & Yes & Convicted & Convicted & $\begin{array}{l}\text { No, DNA could not } \\
\text { be reled upon as } \\
\text { there was no proof of } \\
\text { proper storage of } \\
\text { samples, undue delay } \\
\text { is examination in Lab } \\
\text { and report was not } \\
\text { signed. }\end{array}$ \\
\hline 27 & $\begin{array}{l}\text { State of Punjab } \\
\text { v. Ujagar Singh }\end{array}$ & $\begin{array}{ll}2006(1) & \text { RCR (Criminal) } \\
980 & \end{array}$ & $\begin{array}{ll}\text { Rape and } \\
\text { Murder }\end{array}$ & $\begin{array}{l}\text { Circumstantial } \\
\text { Evidence }\end{array}$ & No & Convicted & Convicted & $\begin{array}{l}\text { No, court said DNA } \\
\text { evidence could have }\end{array}$ \\
\hline
\end{tabular}




\begin{tabular}{|c|c|c|c|c|c|c|c|c|}
\hline & & & & & & & & $\begin{array}{l}\text { to conclusively estb } \\
\text { the fact of sexual } \\
\text { assault }\end{array}$ \\
\hline 28 & $\begin{array}{l}\text { Hari Shankar } \\
\text { Tewari v. State } \\
\text { of Tripura }\end{array}$ & 2005 CriLJ 3323 & Rape & $\begin{array}{l}\text { Oral Evidence, } \\
\text { Forensic Evidence }\end{array}$ & Yes & Convicted & Convictied & $\begin{array}{l}\text { No, DNA reports } \\
\text { could not be relied } \\
\text { upon since there } \\
\text { were contradictory } \\
\text { reports by agencies; }\end{array}$ \\
\hline 29 & $\begin{array}{ll}\text { State } & \text { of } \\
\text { Haryana } & \text { v. } \\
\text { Rewa Singh } & \end{array}$ & $\mathrm{Manu} / \mathrm{PH} / 1164 / 2002$ & $\begin{array}{l}\text { Rape and } \\
\text { Murder }\end{array}$ & $\begin{array}{l}\text { Oral and Forensic } \\
\text { Evidence }\end{array}$ & Yes & Convicted & Acquitted & $\begin{array}{l}\text { No, DNA report } \\
\text { withheld from court, } \\
\text { held to be a } \\
\text { manipulation on part } \\
\text { of prosecution }\end{array}$ \\
\hline 30 & $\begin{array}{ll}\text { Narotam } & \text { v. } \\
\text { State } & \text { of } \\
\text { Haryana } & \end{array}$ & 2004(12) Criminal CC 388 & Rape & $\begin{array}{l}\text { Oral and Forensic } \\
\text { Evidence }\end{array}$ & No & Convicted & Convictied & $\begin{array}{l}\text { No, even though } \\
\text { DNA not conducted, } \\
\text { evidence found to be } \\
\text { overwhelming }\end{array}$ \\
\hline 31 & Mohan v. State & 2011(2) Crimes 355 & $\begin{array}{l}\text { Rape \& } \\
\text { Criminal } \\
\text { Intimidation }\end{array}$ & Oral \& Forensic & $\begin{array}{ll}\text { Yes; } & \text { of } \\
\text { child } & \text { of } \\
\text { victim } & \end{array}$ & Convicted & Convicted & $\begin{array}{l}\text { Yes, helped to } \\
\text { establish the sexual } \\
\text { intercourse with } \\
\text { victim }\end{array}$ \\
\hline 32 & $\begin{array}{l}\text { Babubhai v. } \\
\text { State of Gujrat }\end{array}$ & (2013) 2GLR 937 & Rape & $\begin{array}{l}\text { Oral and Forensic } \\
\text { Evidence }\end{array}$ & Yes & Convicted & Convictied & $\begin{array}{l}\text { Yes, the report } \\
\text { corroborated the } \\
\text { statement of victim. }\end{array}$ \\
\hline 33 & $\begin{array}{l}\text { Asish Mandal } \\
\text { v. State }\end{array}$ & Manu/MH/0630/2008 & $\begin{array}{l}\text { Rape \& } \\
\text { Murder }\end{array}$ & Forensic Evidence & Yes & Convicted & Acquitted & $\begin{array}{l}\text { No, though the DNA } \\
\text { estb presence of } \\
\text { semen of accused in } \\
\text { vaginal swab of } \\
\text { victim, the Court was } \\
\text { not convinced in the } \\
\text { absence of motive. }\end{array}$ \\
\hline 34 & $\begin{array}{l}\text { State of Delhi } \\
\text { v. Manoj }\end{array}$ & MANU/DE/3581/2013 & $\begin{array}{l}\text { Rape \& } \\
\text { Murder }\end{array}$ & $\begin{array}{l}\text { Circumstantial } \\
\text { Evidence }\end{array}$ & No & Acquitted & Acquitted & $\begin{array}{l}\text { DNA evidence could } \\
\text { have helped to prove } \\
\text { the guilt }\end{array}$ \\
\hline 35 & $\begin{array}{l}\text { In Ref. v. } \\
\text { Rajesh \& Anr. }\end{array}$ & MANU/MP/1834/2013 & $\begin{array}{l}\text { Rape and } \\
\text { Murder }\end{array}$ & $\begin{array}{l}\text { Circumstantial } \\
\text { Evidence }\end{array}$ & Yes & Convicted & Convicted & $\begin{array}{l}\text { Yes, helped to } \\
\text { establish the sexual } \\
\text { assault }\end{array}$ \\
\hline 36 & $\begin{array}{l}\text { Jayavelu } \quad \mathrm{v} . \\
\text { State }\end{array}$ & MANU/TN/2604/2009 & Rape & $\begin{array}{l}\text { Oral Evidence, } \\
\text { Forensic Evidence }\end{array}$ & $\begin{array}{l}\text { Yes, of } \\
\text { child born }\end{array}$ & Convicted & Convicted & $\begin{array}{l}\text { Yes, Helped to } \\
\text { establish that child } \\
\text { born was of the } \\
\text { accused }\end{array}$ \\
\hline 37 & $\begin{array}{l}\text { State of HP v. } \\
\text { Diwan Thapa }\end{array}$ & MANU/HP/0342/2013 & Rape & $\begin{array}{l}\text { Oral and Forensic } \\
\text { Evidence }\end{array}$ & No & Acquitted & Acquitted & $\begin{array}{l}\text { Absence of DNA } \\
\text { significant }\end{array}$ \\
\hline 38 & $\begin{array}{lr}\text { Md. Ekram } \\
\text { Hussain r. } \\
\text { State of }\end{array}$ & $\mathrm{Manu} / \mathrm{GH} / 0321 / 2013$ & Rape & $\begin{array}{l}\text { Oral \& Forensic } \\
\text { Evidence }\end{array}$ & $\begin{array}{l}\text { Yes, of } \\
\text { child born }\end{array}$ & Convicted & Convicted & $\begin{array}{l}\text { Yes, helped to } \\
\text { establish paternity of } \\
\text { accused }\end{array}$ \\
\hline 39 & $\begin{array}{l}\text { Vikram Kumar } \\
\text { v. State of } \\
\text { Delhi }\end{array}$ & MANU/DE/1336/2013 & Rape & $\begin{array}{l}\text { Oral \& Forensic } \\
\text { Evidence }\end{array}$ & Yes & Convicted & Convicted & $\begin{array}{l}\text { No, DNA evidence } \\
\text { not relied upon as it } \\
\text { indicated nothing to } \\
\text { link the accused to } \\
\text { the offence; oral } \\
\text { testimony held } \\
\text { credible }\end{array}$ \\
\hline 40 & $\begin{array}{l}\text { Kaini Rajan v. } \\
\text { State of Kerala } \\
(\mathrm{SC})\end{array}$ & 2013 (!!) SCALE 606 & Rape & Oral Evidence & No & Convicted & Acquitted & $\begin{array}{l}\text { Yes, absence of DNA } \\
\text { to prove the paternity } \\
\text { of child, other } \\
\text { evidences also not } \\
\text { cogent }\end{array}$ \\
\hline 41 & $\begin{array}{l}\text { Rewa Ram } \\
\text { Sahu v. State }\end{array}$ & 2012(4) CGLJ 464 & Rape & $\begin{array}{l}\text { Oral \& Forensic } \\
\text { evidence }\end{array}$ & No & Convicted & Acquitted & $\begin{array}{l}\text { Absence of DNA } \\
\text { significant, held after } \\
\text { Section 53A, DNA } \\
\text { test is compulsory }\end{array}$ \\
\hline 42 & $\begin{array}{l}\text { Padam Singh v. } \\
\text { State of HP }\end{array}$ & MANU/HP/1757 2012 & Rape & $\begin{array}{l}\text { Oral \& Forensic } \\
\text { Evidence }\end{array}$ & Yes & Convicted & Convicted & $\begin{array}{l}\text { Yes, DNA linked the } \\
\text { accused to crime }\end{array}$ \\
\hline
\end{tabular}




\section{Copyright Disclaimer}

Copyright reserved by the author(s).

This article is an open-access article distributed under the terms and conditions of the Creative Commons Attribution license (http://creativecommons.org/licenses/by/3.0/). 